\title{
Why Universalism?
}

\author{
Alison Assiter* \\ *Correspondence: (Alison.Assiter@uwe.ac.uk)
}

\section{Abstract}

This essay argues that there are reasons why all groups, including feminists and those who are critical of forms of fundamentalism, need a perspective of universal humanity. Universalism is important because it is a view about the shared characteristics of all humans. It is particularly necessary to reiterate that there are such qualities in a world where ugly divisions between groups have once again become apparent. Universalism is also a normative perspective - a view that there are principles of justice that require that each person, whoever and wherever they are, is treated fairly and equally. With appropriate qualifications, I suggest that universal

Peer review: This article has been subject to a peer review process.

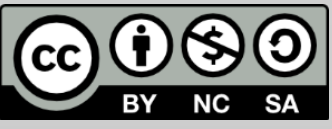

(C) Copyright: The Authors. This article is issued under the terms of the Creative Commons Attribution NonCommercial Share Alike License, which permits use and redistribution of the work provided that the original author and source are credited, the work is not used for commercial purposes and that any derivative works are made available under the same license terms. nature can be understood in terms of needs, or indeed of rights, so long as the limitations of the latter are appreciated. The essay responds to criticisms of a universalist perspective--from the post-modern to the view that universalism is invariably a false generalisation from a partial point of view. I suggest that sometimes these positions misrepresent universalism. At other times, though, they make better sense if they are construed as presupposing a universalist perspective.

Keywords: Universalism; post-modernism; intersectionality; justice; needs; rights; feminism; fundamentalism.

In my 2003 book Revisiting Universalism, I defended a universalising perspective, a view that suggests that there are political and moral 
imperatives deriving from the fact of our universal humanity. In this essay, I will argue that there are reasons why all groups, including feminists and those who are critical of forms of fundamentalism, need a perspective of universal humanity. Given, however, that many theorists have challenged universalism, I will spend some time responding to critics of the viewpoint. I will then move to consider some alternative theoretical perspectives, including feminist outlooks, that have been offered as countering universalism. In the course of this, I will suggest, contrary to the view of some post-modern feminists, that there are also reasons, in certain circumstances, for defending a notion of universal 'woman'.

What do we mean by 'universalism' about humans? We mean a view that there are broad shared characteristics of humanity. But universalism is important because it is also a normative perspective - a view that there are principles of justice that require that each person, whoever and wherever they are, is treated fairly and equally. Human beings have, as Martha Nussbaum has put it $(\mathbf{1 9 9 5 , 5 ) : ~ ' a ~ d i g n i t y ~ t h a t ~ d e s e r v e s ~ r e s p e c t ~}$ from laws and social institutions'. Respecting human dignity might entail drawing up a set of human needs or rights deriving from these and respecting these. Included amongst those needs or rights that are either basic or very important would be the right to life, the right to decent food and shelter and the right to freedom from persecution. The satisfaction of basic needs is necessary to ensure human flourishing. This point might be made in terms of needs or in terms of capabilities but, with appropriate qualifications, to be adumbrated below, and as outlined above, it could be conceptualised in terms of some notion of a right. Underlying the notion of a right is the view that individuals are entitled to respect as moral agents capable of making choices. Moreover, while the notion of a right is in fact associated with liberal citizenship, it is possible to re-think the notion in a fashion that may be more in accord with a genuine conception of universal humanity. 
In my personal view, which I have defended elsewhere, ${ }^{1}$ a universal perspective is best defended in terms of the common nature shared by all of the members of humanity. This common nature is a rich and diverse one and it suggests our deep connection with the rest of the natural world. This shared nature need not be an exclusively objective one. As Françoise Lionnet $(1991,2-3,4)$ has suggested in her deeply engaging discussion of FGM, a universalist perspective on the body need not 'objectify the other'. Rather it is possible to suggest a form of universalism that creates a space where 'inter-subjectivity and reciprocity become possible'. Lionnet argues that the discourses on FGM of both early feminists and some of the more recent post-colonial theorists are misleading. She contends that accusations of 'western imperialism' and African barbarism are both empirically wrong and that each underplays African opposition to the practice.

In 2003 I argued that one central reason why it is important to defend a universalist theory about human beings is to characterise the shared humanity of, for example, the poorest person in the world and the richest person. Economic injustice is perhaps one of the most extreme types of injustice. A recent Oxfam report, from January 2015, suggests that the richest 1\% will own more than all the rest by the year 2016 (Slater 2015). These figures themselves are enough to give any of us pause for thought. The Ebola outbreak illustrates, indeed, the kinds of threat posed even to the richest in the world by these damaging levels of inequality. A virus of this kind does not distinguish rich from poor, although, of course, the rich are likely to have access to health care that is unavailable to the poor. Unless the richest recognise their shared humanity with the poorest, then the poorest are liable to be written off as either implicitly not human at all or as possessing some inferior form of humanity. Extreme levels of inequality anyway, are detrimental to the well-being of all (see Wilkinson 1996). Economic and political instability, consequences of extreme levels of inequality, are detrimental, in the long run, even to the interests of the 
rich. One can make parallel kinds of points though, about other areas of difference, including sex and gender differences, between groups of people. The World Economic Forum reports annually on a range of inequalities between men and women and suggests that these are significant across a range of indicators - including pay for similar jobs, educational attainment, political empowerment and health and survival (see Hausmann et al 2014).

A further example of an injustice is the denigration of the female body in certain forms of fundamentalism. While it is important for me as a white western woman to be careful not to offer an 'orientalist' or a western perspective on Islam, it is also necessary to point out injustices perpetrated by 'fundamentalist' forms of religion. One writer, Mariam Poya, an Iranian and Muslim woman, reserves the term 'fundamentalism' for a version of Islam that is about 'absolute control over the female body and mind' (Poya 2000). It is a normative perspective of universal humanity that allows us to see this as an injustice.

Of course, even these claims involve what might seem a paradoxical challenge to universalism. If some groups challenge universalism then how can a universalist outlook be applied to them? How can I claim an attachment to universalism on the part of the very groupings that set out to challenge the notion? However, those groups need to recognise the importance of universalism if humanity is to flourish. Social and cultural groupings do not live in isolation from one another.

\section{Some common criticisms of universalism and some responses}

Some of the above claims about the significance of universalism might seem obvious. But the basic position has been criticised from a number of different perspectives. One criticism of universalism concerns its scope. So, to take one example of this criticism, in his important monograph, The 
Black Atlantic, that argued for a cross diasporic conception of 'black identity' against an Enlightenment ideal that was partially constructed on a premise of slavery, Paul Gilroy wrote $(1993,43)$ : 'incredulous voices have drawn attention to the bold, universalist claims of occidental modernity and its hubristic confidence in its own infallibility'. Gilroy's work, alongside that of others, has demonstrated the exclusionary nature of certain Enlightenment concepts. Some Enlightenment thinkers actually excluded women and certain races from the scope of the notion of a right, and, more significantly, as noted above, Gilroy's work demonstrates how slavery was in fact part and parcel of certain elements of the Enlightenment ideal. ${ }^{2}$ Human universality, then, has been seen as an Enlightenment conceit; it has been viewed as inevitably presupposing the imposition of purportedly and falsely 'universal' values on those falling outside its invariably European and white norm.

This point has also been expressed in a slightly different form by those who have argued that the very idea of a civic public which is implicit in universalising thinking excludes groups defined as different (see Young 1989, 250-74). The notion of a republic or of citizenship, it has been argued, is always implicitly racialised or sexed. Such a critique of universalism, however, might indicate that the 'universal' outlook against which the comment inveighs, is not genuinely universal. Moreover, the criticism probably assumes, with its reference to 'Enlightenment conceit', that universalism is to be conceptualised in terms of the discourse of human rights.

Radically different thinkers, ranging from the Marxist inspired intellectuals Horkheimer and Adorno in the Dialectic of Enlightenment $(2002)^{3}$ to the defender of certain religious communities, Saba Mahmood (2011), have critiqued the notion of a right and damned the liberal self with faint praise. Horkheimer and Adorno argued that the domination of nature by humans and of one group of humans by another is endemic in Enlightenment thinking and that the discourse of human rights is core to 
this frame. Horkheimer and Adorno suggested that progressive forces, in Enlightenment discourse, are undermined by the links between the enlightenment commitment to freedom and equality and capitalist excesses. ${ }^{4}$ This work poses a challenge to the normative assumptions underlying the liberal conception of the self. ${ }^{5}$

There is not the space in an article of this kind to respond properly and in depth to these significant challenges to liberal thinking. However, it is possible to respond that these interpretations of the notion of a 'right' suggest not that the concept itself, or its underlying values, is problematic but that its associations, with capitalism, individualism, sexism and racism represent inappropriate and partial interpretations of the notion. The notion of a right, if it is understood in a genuinely universal way, need not be viewed in terms of Enlightenment autonomy, with its ready association with individualism and its denial of the interconnectedness of humanity. One might note, moreover, that the conceptualisation of freedom, to take one value-laden concept, often associated solely with the Enlightenment, is core also to ancient Greek thinking. Hannah Arendt, for example, in her magnum opus, The Human Condition (1958), drawing on the ancient Greeks, emphasises how true action of human beings - for example political activity that recognises and depends upon the activity of others requires some notion of freedom. In fact, for her, the modern world is characterised by the denial of this form of action, action that ought to characterise a feature of humanity as distinct from animality.

Moreover, having available to us, in our contemporary globalised world, a notion of universal humanity does not mean that we ignore the cultural, religious, sexed and racialised aspects of our identities as humans. If the notion of a right, therefore, were genuinely founded upon a conception of universal humanity, or on the needs and the flourishing, appropriately construed, of such a universal humanity, then it would not fall foul of these objections. 
It is true, to reiterate points that have frequently been made, that specific exemplifications of human rights, as enshrined in legal constitutions and in the conceptions of citizenship deployed by particular nations, often fail to promote universal standpoints. Frequently the rights that are enshrined in the various legal systems, even of purported democracies all over the world, violate the notion of equal respect. Sometimes laws and institutions themselves perpetuate inequalities on grounds of sex or race, class or religious affiliation. ${ }^{6}$ It is also important to mention those individuals who are stateless and who don't therefore have the protection of the law anywhere. Migrants often don't have 'rights' at least expressed in the form of citizenship of some state, anywhere. In the UK, 'terror suspects' are increasingly defined as being 'outside' the universal convention that allows them at the very least the right to life and the right not to be tortured. There are also extreme zones of exception such as Guantanamo Bay set up by the US government as part of its 'war on terror' policy.

But, to reiterate the point once more, these expressions of the limitation of the notion of a right do not mean that we should reject altogether the discourse or the concept of universalism. It doesn't follow from the fact of the imperfect application of principles of universal rights that the notion of universal rights itself ought to be rejected, nor does it follow that the concept itself is racist or Eurocentric or sexist.

Although, therefore, the concept of a 'right' as it is often interpreted, is flawed and is an imperfect tool, it is nonetheless a vitally important one. The significance of it, even in the liberal terms articulated in the Universal Convention, is highlighted by the recent threat, in the UK, to the Human Rights Act. The Conservative government in the UK at present is considering seceding from the European Convention on Human Rights.

Returning, then, to the claim of Gilroy, Gita Sahgal (2014, 67-83), for one, has forcefully challenged the view that a secular universalist human 
rights perspective stems exclusively from European Enlightenment values and a European context. Indeed, she has argued that the movement in India that challenged the twin ills of colonialism and fundamentalist Hinduism was, and still is, the universalising discourse of human rights. ${ }^{7}$ Moreover, and relatedly, Chetan Bhatt (2006, 98-115) has critiqued the ready association of non-western with 'victim' and 'other'. He suggests an association of this with the simultaneous denial both of full subject-hood to the 'subaltern' or the 'non-western' and of the possibility that some such 'victims' might themselves also be attacking, for example, the secular spaces of Asian peoples.

Finally, on this point, Neil Lazarus and Rashmi Varma (2008), make the following point: 'From the Haitian Revolution of the late eighteenth century to the Indian freedom struggle of the mid-twentieth, from Toussaint L'Ouverture's challenge to French ideas of citizenship to Gandhi's strategic ironisation of 'Western civilisation' as a 'good idea' (his tongue-in-cheek suggestion, of course, was that it would be a good idea if the West were to become civilised!), the history of anticolonial struggle is replete with instances not of 'alternative modernity' but of claims made to civic rights, freedom and citizenship on the ground of modernity' (326).

\section{Atomistic individualistic 'pseudo' universalism}

A second criticism, along similar though differently conceived lines to that of Gilroy, claims that a 'universalist' perspective is a chimera - it rests on a god's eye view of the world that is simply unattainable. So, for example, critics of Rawls' ${ }^{8}$ self - the self that negotiates about norms from behind a 'veil of ignorance' - claim that such a self is a fiction. A 'universal' self is such a watered-down self that there is nothing left. Moreover, the 'liberal' universalist relies, it is said, also, on an 'individual' notion of the self, that is isolated from its communities, its cultures and its traditions. 
'Liberal' and other political thinkers therefore countered universalism with communitarianism. In its communitarian version, liberal pluralists suggested that a community or a society is important for a moral theory to have practical force. Waltzer (1983) and Taylor (1992), for example, claimed that it is vital that we stay rooted in our communities in order to make sense of our shared ethical values. The self, according to this argument, is always 'encumbered' in its traditions, its cultural norms and its communities and it is these 'encumbrances' that form the basis for its values. As Gideon Calder has put it $(2006,5)$, 'every universalism masks a particularism'. Post-modernists, post-colonial theorists, some feminists and others advise us to focus on our differences, to celebrate our diversity. Many in western liberal democracies responsible for the policy enactment of views like this therefore developed policies that prioritised the values of communities. ${ }^{9}$

There is an important general point to make about this, however. First of all, while 'particularists' claim that the universalist cannot specify what it is that is universal in humanity, the universalist will counter that 'particularists' suffer from the same difficulty. For 'particularists' it is equally difficult to specify what form the 'encumbrances' ought to take. ${ }^{10}$ So Rorty, for example, on the one hand, throughout his work, has expressed concerns about potentially false universalising perspectives, about any normative view that purports to be universal but that might not be. One should, he writes, 'face(s) up to the contingency of his or her own most central beliefs and desires' $(1989, x v)$. On the other hand, he claims, one must also create some kind of solidarity with others. But, the universalist might ask, what does this 'solidarity' mean and with whom? With a nation, for example; with a particular culture? Why? What about those excluded from the scope of the nation or the culture?

A central difficulty for this view of Rorty's is that it is difficult, without recourse to some notion, however nuanced, of universal humanity, for this sense of solidarity to be anything other than arbitrary. It will become 
either a local community or a nation, or a cultural grouping and the question will arise in relation to each of these - why should we prioritise any one of them? In the end Rorty, indeed, himself reverts back to a notion of universality - a conception of universal vulnerability. Humans, for example, are frail beings subject to pain.

Moreover, and equally importantly, the view that the universal self is an unencumbered 'mind' that exists everywhere and no-where seems to rest upon a metaphysical view of the self that is ultimately in some sense Cartesian - the self as a 'mind' that has, as Kant pointed out, no identifying characteristics other than the fact of its thinking. But the universal self does not have to be construed this way. It can instead be viewed as a living, active, embodied self that is differentiated from other animals and from the rest of the natural world by its ability to devise norms and by its particular type of consciousness. The norms devised by such a self may change but they must include a constant and vigilant concern to protect the rights and abilities of all human beings, wherever they find themselves and with whomever they associate in their relations with others.

Thus universalism does not have to depend on a God's eye conception of the human self. The parameters of the human are fluid - technology in all its forms, for example, shapes what we know and count as human - but the human is always embodied and finite, rather than being, as the critics assume it to be, a strangely disembodied mind. In the end, then, this criticism of universalism is no different from the one expressed by Gilroy, since it identifies, mistakenly I am suggesting, all forms of universalism with the 'Enlightenment conceit'.

\section{Criticism of the notion of justice}

It is important also to mention those critics who have associated the very principle of justice with the Enlightenment conceit. So, for example, feminist political theorists have argued that the notion of justice itself 
depends upon an inappropriate view of the self. Carol Pateman, for example, in her major and significant work The Disorder of Women: Democracy, Feminism and Political Theory $(1989,3)$, argued that the very discipline of political theory 'systematically excluded' the question of women from its frame of reference because it was based on the conception of a public citizen that excludes the private realm of the family. Feminist political theory, since the publication of that text, has been engaging in responding to this point either by re-thinking the notion of the 'public' or by extending some of the aspects of citizenship into the private sphere. Extensive feminist work, for example, has been done on domestic violence issues. ${ }^{11}$

But the point has also been made that the principle of justice depends, in the words of Iris Marion Young, on an ideal of impartiality that is the 'same for all rational agents' $(1990,100) .{ }^{12}$ Young argues that developing principles of justice requires a point of view that abstracts from particularity, from context and from emotion. This, however, according to her, involves an inappropriate denial of difference or 'alterity' amongst subjects - differences arising from situation, context and other aspects of individuality. The ideal of normative reason, according to her, necessarily underplays differences between subjects. Deploying principles of justice, then, on this argument, necessarily leaves out important characteristics that differentiate humans from one another.

Young's argument is an important and a strong one. One way of reading it, however, is that it associates principles of justice with the form of universalism - the atrophied self - that has been critiqued in the previous section of this article. But secondly, Young seems to go further and claim that universalism is impossible because of the logic of identity that it presupposes. Every concept has an opposite. If, for example, the universal concept is reason, then it necessarily excludes emotion. However, as I have argued before, characterising humans in a minimal sense does not entail that they are only and exclusively that minimum. As argued previously, 
describing human beings in terms of a universal nature or a universal form of reasoning does not mean that they are not also emotional, culturally embedded etc. So the criticism of the ideal of justice then, depends in part on a critique of a conception of universalism that has already itself been challenged in an earlier section of this article.

\section{A Response to one further criticism of universalism}

Moving now specifically to some feminist critics of a form of universalism, but a universalism now about women, post-modern inspired feminists challenged their early second-wave sisters. Their main criticism of the latter paralleled the above challenge to universal humanity. It was that many of the claims that purported to be universally true of women were in fact true only for women of particular classes, races and cultures. Abortion on demand, for example, was not a demand that those women undergoing forced contraception could relate to. Post-modern feminists, then, suggest that the early feminists unconsciously and falsely universalised from their own perspectives. These criticisms followed on the heels of the earlier feminists' insistence that their male counterparts had universalised from their own partial perspective. Some post-modern inspired feminists therefore concluded that there are no 'essential' or 'universal' characteristics of women.

In this vein, post-modern feminists argued that feminist theory must be 'explicitly historical' and 'non universalist' (Fraser and Nicholson 1990, 19-38). One significant pair of writers on the subject, Linda Nicholson and Nancy Fraser, criticised earlier feminists on the ground that their theories were 'essentialist and mono-causal'. They also described universalising theories, in Lyotardian vein, as 'quasi metanarratives' (ibid., 27). As another writer on the subject put it: such theories falsely universalised features of the theorists' own 'era, society, culture, class, sexual orientation, and ethnic or racial group'. In fact, to give one example, these writers argued 'there are no common areas of experience between the 
wife of a plantation owner in the pre-Civil War south and the female slaves her husband owns' ${ }^{13}$

Post-modern feminists, then, as noted, drew on the work of Lyotard. In his classic text on the subject, The Postmodern Condition (1979), Lyotard had objected to the 'foundationalism' implicit in what he labelled 'grand narratives' as well as to their Enlightenment inspired and falsely optimistic faith in progress. In response to this, however, firstly, Lyotard's critique of the notion of a 'grand narrative' has not gone unchallenged. His description of contemporary science as being concerned with 'paradox, fracture, catastrophe' has been questioned (see Rorty, Habermas and Lyotard in Bernstein 1985, 163). Secondly, it is important to note that it is possible to believe in a universal theory without upholding a foundationalist epistemology (the desire to place knowledge on claims that are known with certainty). Thirdly, and most importantly for the present issue, it is, to reiterate the point, possible to uphold a universalist outlook about women, as well as about humanity more generally, without falsely generalising from one's own perspective. As Margaret Whitford once put it $(1991,5)$, feminist membership is like Merleau-Ponty's heap of sand: each grain individually is minute and slightly different from all the others, but the whole sandbank may block a river. ${ }^{14}$

'Woman' is multiple; there are many classes of women, many races and many sexual orientations. Perhaps each one of these has come into being as the result of a number of processes or as the expression of a number of powers. Some of these powers are biological; some are social. However, universality in the following sense is undeniable. Each kind of thing is categorised on the basis of shared characteristics of that kind. It would be impossible to categorise anything at all unless this were the case. The category human and the category woman are no different. It doesn't follow from the claim that all women are different that we must celebrate differences and deny universality. Moreover, the category 'woman' can also be used normatively, in an analogous fashion to that of humanity, to 
critique unjust practices amongst women. There may be disagreements about what constitutes an injustice - abortion on demand may be perceived as a right by some women and not by others. Yet there are cases - FGM for example - where the practice would be agreed by many women to constitute an injustice against women. It is a recognition, once more, of shared membership of the universal that allows for this.

Some post-modern inspired feminists, it is arguable, in their desire to denigrate what was called hetero-normativity may have thrown out the ability to theorise male power. ${ }^{15}$ The ontological conception of the human which is at least partially biologically formed, needs to be reinstated. This point has been made recently by Elizabeth Grosz (2011), who argues that it is Irigaray who recognises the huge significance of the division between the sexes in any ontology. It is notably Irigaray, according to Grosz, who has focussed on the ontological reality of sexual difference, sexual difference as a mode of being, ${ }^{16}$ rather than a pair of objects that is discovered in the world. For Irigaray, reflecting Darwin, nature itself is sexed - it is at least two. ${ }^{17}$ This division, according to Irigaray, cuts across all living beings, and is the condition for the emergence, in the human, of all other differences. An appreciation of this point does not mean that it is not also important to recognise the phenomenological experience of individual women. It is very important not to impose on, for example, the experience of someone who has undergone FGM, a point of view that is not derived from that experience. The vivid account of the phenomenon offered, for example, by Nawal El Sa'dāwī, in A Daughter of Isis (1999), viscerally conveys the horror of the experience for her and could not be conveyed by someone who had not experienced FGM.

Biologically sexed bodies are also socially inflected. Moreover, biology itself may be subject to norms. But it does not follow from this that the biological and the social are reducible to one another. A universalist inspired criticism of some post-modern feminists, then, which is also a criticism of the 'false' version of universalism critiqued by Gilroy and 
others, is that they may underplay biological bodily identity. Even if this view about biology is not accepted, it remains the case that, for normative reasons, there is a universal category 'woman'.

\section{'Identity' politics}

For certain post-modernist feminists and for the early Rorty, although they conceive of identity differently from one another, all of us are, in some crucial sense, defined by our 'identity'. This identity may be performatively constructed, as it is with Butler, or simply given. For Judith Butler (1990 and elsewhere), for example, at least in so far as she has been read by some, identities can be made and re-made through performance. For some readings of her work and for the early Rorty, though, identities are both 'foundational' and, simultaneously, they express the normative interests of subjugated groupings.

I would like to note at the outset that the notion of identity is a very important one in certain contexts. There needs to be institutional recognition of oppressed groups. As Iris Marion Young has put it, 'a person's particular sense of history, understanding of social relations and personal possibilities, her or his mode of reasoning, values, and expressive styles are constituted at least partly by her or his group identity' (1990, 259).

But there are 'universalist' comments one can make about this theoretical perspective that assumes that 'identity' is paramount. One criticism is this: a point that is not often noted, to take one example, is that an investment in 'black' identity carries with it a counter investment in 'white' identity - in the US 'whiteness' appears to provide one with access to resources, power and opportunity (Lipsitz 2006). Yet whiteness is less frequently discussed than blackness in the elaborations of 'identity' 
politics. As Richard Wright put it when asked about his view of the 'Negro' problem, 'there isn't a negro problem; there is only a white problem' ${ }^{18}$

To express what is problematic about this: identity politics may only represent the interests of the grouping rather than remedying injustice. This is not to deny that these interests are very important and that political activity on the basis of these interests has been what has drawn attention, for example, to the issue of racism. Identity is also important for the recognition of the group.

However, it is also the case that it is an injustice rather than merely in the interests of black people that black people in the US, for example, are poorer than white people. A specific illustration of the problem of interests is that there is sometimes 'interest convergence' between a powerful and a disadvantaged group e.g. the case of de-segregation: it was initially in the interest of some whites to oppose segregation for economic reasons (it would favour development) rather than because segregation is racist and wrong. But this wholly ignores the problem of the injustice of disadvantage. Framing politics in the form of identities fractures the civil polity and fails to create opportunities for ending marginalization. Black inequality is an issue for all, rather than merely being one for black people. It requires a perspective of shared humanity and of justice to see that black inequality is unjust. Although it took a specific group to point this out, the injustice must be an issue for all.

A third difficulty is that problematic versions of the political position arise when a defence of the 'identity' of any one of these groupings becomes either a failure to recognise multiple forms of oppression, on the one hand, or, more controversially, circumstances when individuals or groups within such identified collectivities become themselves oppressors. Communities, in general, are important when they allow for the flourishing of all. Where they work against this, then they cease to be valuable. The identity of being Jewish, or Christian, for example, while it is 
important in representing the interests of Jews or Christians, may gloss over inequalities and injustices within the collectivity.

Moreover, the focus on identity omits reference to areas of existence that are outside the control of the subject. Elizabeth Grosz, referred to earlier, seeks to problematize the focus in much contemporary feminist philosophy, on identity. She suggests that the concern, in much feminist theory, with the subject's feelings, identity, affects, agencies and energies and related issues, leaves out the 'rest of existence' - what is outside the subject or outside the control of the subject.

\section{Inter-sectionality}

There has been a popular theoretical response to the perceived limitations of 'identity politics' which has become known as 'inter-sectionality'. This term was coined by Kimberle Crenshaw (1991, 1241-1299), who is an African American critical legal theorist. According to inter-sectionality theory, people are constructed, as Sukhwant Dhaliwal and Nira Yuval Davis write (2014, 35): 'along multiple (and both shifting and contingent) axes of difference, such as gender, class, race and ethnicity, stage in the life cycle, sexuality, ability and so on'. The intersections are not simply added together but rather they constitute each other, so it is impossible for any individual, according to the theory, to be identified by means of any subset of the categories.

I would like simply to pose some questions about this theoretical approach. First of all, how do we know where to draw the line? How many 'inter-sectional characteristics' are allowed or perhaps more importantly, how many should be taken into consideration at any one time? How do we determine which characteristics are politically significant? Most of the contributors to the debate refer to the 'intersections' of class, race and sex. But are these the only kinds of division that are politically significant? Could one include, for example, religion or culture? How would the 
inclusion of these additional categories affect the way in which the 'social divisions' are conceived and would it affect how they interact?

Is it possible to explain, for example, sexism within a particular religion in terms of the 'intersection' of divisions? Is it not clearer to explain such a practice simply as unjust? Does it not require a view that there is a universal humanity and that all should be treated fairly and well, to see this?

Inter-sectionality theorists critiqued early feminist 'dual systems' or 'triple systems' theories on a couple of grounds: sometimes sex and race operate together to produce a form of oppression that is distinct from either race or sex oppression separately. It is also said that gender relations are formed inside class relations and this is thought further to undermine the notion of them being separate systems.

But it doesn't follow just because gendering takes place inside class relations that gender is not a separable theoretical 'system' from class. It also doesn't follow, as I have argued earlier, just because each one of us is comprised of many intersecting and variable characteristics, that we cannot also be characterised in the terms that all of us share. But more importantly, the same kind of point can be made about this theory as was put earlier about identity theory. While the notion of intersecting systems of gender and race for example plays a useful methodological role in enabling certain kinds of research, policy and activism, if we are concerned, by contrast, to emphasise the injustices committed against certain groups or individuals through the intersection of, for example, oppression based on sex and race, we require a universalising outlook to make sense of this as an injustice. Discrimination against a person on grounds of the 'inter-section' of race and sex involves a dual injustice. It is a universalising perspective that allows us to make sense of this. Intersectionality, then, presupposes a universalising perspective. 


\section{‘Oppressors' within marginal groupings}

Moreover, neither identity politics nor inter-sectionality without universalism can address the equally important question of those who are 'oppressed' in certain circumstances becoming 'oppressors' in others. So, while it is the case that racism in general or 'racism' against Muslims or other religious groupings, or discrimination against Christians (expressed in many parts of the Middle East and elsewhere today) are each unjust and oppressive practices, it is also true that fundamentalist forms of religion are themselves oppressive and unjust and ought to be condemned.

A seriously problematic interpretation of communitarianism or identity politics, therefore, is when 'community' values, like, for example, reactionary and extreme views about gay people or about women, are allowed to reign unchecked within certain 'communities' or are allowed to represent the 'identity' of the community. Such cases obviate the reason for community or multi-cultural values being significant in the first place. Communitarianism or multi-culturalism, to reiterate, are significant when they work to promote the flourishing of all. When they cease to do this, they cease to have this value. As Pragna Patel (2013) has pointed out, (selfappointed) community leaders often become the spokespeople and therefore the 'authentic voice' of certain communities and this is harmful to less powerful groups within those communities. Patel speaks of the way in which the religious right in certain 'ethnic minority' communities in the UK has been granted representative status. One extreme example of the effect of this is the furore surrounding the play Behzti, a play about sexual and 'honour' based violence in a Sikh temple. The play exposed corruption and abuse of power within the Sikh community. The play was pulled by the Birmingham Repertory company in the face of protests from within the Sikh community. These community members attacked the play citing the ground of religious hatred, forcing the author, herself a Sikh, to go into hiding. 
As Patel also points out, the religious right is on the rise at the same time as racism towards minorities and especially Muslims is on the increase. This illustrates, to reiterate again, the need for a universalist perspective: It is only a belief that both anti-Muslim racism and anti-sexism within so-called 'Muslim' communities are unjust, that allows and indeed requires all of us to condemn both. It is also these beliefs that form the basis for political action that can unite people across communities and identities.

A case that fascinated me was the view of a Muslim woman from the Sudan who expressed her shock at the right-wing versions of Islam held within some Muslim communities in the UK. ${ }^{19}$ Perhaps right-wing versions of religion have been allowed to flourish at least partly because of practices on the part of many in the UK of inappropriate applications of multi-culturalist and 'community' forms of pluralism. In their desire not to fall foul of the supposed Enlightenment conceit, well-meaning nonuniversalist liberals may have inadvertently allowed pernicious and rightwing values to take root in some of the multi-cultural communities they argued should be tolerated.

It is important to note, of course, that 'right-wing' values within communities specifically in the UK have also been tolerated in cases like working men's clubs (some of which still exclude women) or, at the other extreme 'gentlemen's clubs'.

In this context, it is again a universalising perspective that recognises our collective shared humanity and the needs and rights that stem from this, that is the best theoretical approach to adopt. A universalising perspective at least recognises a number of key and core rights - the right to be free from religion as equal to the right to practise religion, the right to be treated equally as well as rights to be free from racism, sexism, antiMuslim racism and homophobia. It is on the basis of our shared humanity that it is possible to theorise a perspective that recognises all of these as rights. Racism denies the humanity of those affected by it. Anti-Muslim 
racism may be different but, in its extreme variants, it tends to damn all Muslims as right-wing fundamentalists. Failure to recognise the rights of cartoonists to lampoon religious characters, the rights of all to be free from religious persecution, the rights of all to be free from sexism is a failure to recognise the rights of all to flourish as individuals and as groups.

It is a universalising perspective about humanity that allows us to recognise that crimes against humanity have been committed by powers, like, for example, Saudi Arabia as well as by states like the USA. One lesser known such crime is the collusion of the Jamaat-e-Islami and the Pakistani army against secular nationalists and religious minorities in 1971 (Sahgal 2014). Indeed, it may be the denial of the possibility of a universalising perspective that leads some in the west to castigate as racist white people who set out to critique such practices. As noted earlier, leftist 'multiculturalism' has encouraged the naming of 'non-westerns' as victims rather than fully fledged members of universal humanity, and a corresponding reluctance to critique right-wing religious ideologies. As Chetan Bhatt has put it (2006, 98-115): 'Also of importance is the inert, innocent nature of the agency and subjectivity that left culturalism imparts to non-western subalterns and western diasporics, a kind of heroic, narcissistic, victimology that cannot name itself as such. In much multicultural theory, the diasporic subaltern is primarily a culturallydescribed, infra-ethical victim rather than a subject fully capable of ethical existence and judgment.'

\section{Conclusion}

In this essay, I have argued that it is important to defend some notion of universalism - universalism about humanity, on the one hand, and about women as well, in certain circumstances. I have given a number of reasons for these positions, and I have critiqued some proposed alternative theoretical perspectives. I have suggested that there are several ways of 
defending universalism, one of which is the view that there are universal rights that apply to all, wherever and whomever they are. Sometimes, indeed, it will be important to use the notion of universal humanity to critique inappropriate applications of the notion of universal womanhood.

One reason, pertaining to this journal, why it is important to retain the notion of a right applying to all of humanity, despite its limitations, is the opportunity it offers to counter, for example, 'sharia' law, which 'aims to replace the sovereignty of the people with the sovereignty of God, as revealed through the Sharia' (see Ruthven 1997). According to a number of Iranians, gender apartheid has been the fundamental principle of their regime, based on a version of Sharia law.

The notion of human equality before the law is a useful device with which to challenge a view that sets out to enshrine into the constitution the view that men and women are 'different types of human' (Motahhari 1990). There are many other positions analogous to this Iranian example, but the perspective of human rights that apply to all is useful to challenge any such view.

I would like to conclude the piece by suggesting why I personally believe that, in the end, it is the shared natural nature of all of us that constitutes our universal humanity. Human beings are natural beings. This need not be a reductive notion. Humans are not merely animals. But our animal nature is a deeply significant aspect of our being. We all share with the rest of the natural world a dynamic, evolving biological nature. This nature both encompasses all of humanity and also stresses the need on the part of humanity for a shared concern for the non-human nature from which we all derive. Humans differ from other animals, however, in one respect which is universal to all of us, which is that we are able to develop norms of justice and equality. Such norms ought to encourage us to respect the humanity and the flourishing of all members of the human species. Identity theorists, 'performativity' theorists and those who 
believe in inter-sectionality all require universalising notions of justice and these notions are themselves, in my view, grounded in our common humanity.

Particularists, relativists and pluralists have criticised what has passed for universalism. Properly conceptualised, universalisms are neither Eurocentric nor partial. A universal view of nature need not offer a reductive and mechanistic view of human nature. Rather it could view all human beings as biological and natural beings but who are different from all other animals in having the ability both to commit horrendous crimes but also to recognise the rights of all to flourish. Although biology is shaped by race, class, sex etc. this does not make it any the less biological. Biological characteristics are themselves 'performatively' shaped by environment and culture. ${ }^{20}$ They are not exclusively 'innate'. The same point applies in relation to any one of the categories. Each is shaped by all the others and yet it retains its distinctiveness. Reducing any one characteristic to any one of the others - the biological to the social or vice versa - involves a form of reductionism. Social reductionism is as much a form of reductionism as biological reductionism. We humans share some qualities with elements of the natural world from which we, as humans, have emerged but we are also uniquely able to recognise the harm that humans have done to this natural world.

When postmodernists and others critique what has passed as universalism they have derided it as an "Enlightenment" conceit'. Unfortunately the perceived problems with some aspects of the 'Enlightenment' model of the self have led to misguided and unfortunate challenges to the very notion of universalism about humanity.

Our universal humanity rests partly on biological realities but these need not, as has been illustrated here, be read in a reductive manner. Nor are they, as some have suggested they are, trivial qualities. Indeed, to the contrary, our shared basic biological needs are the bedrock set of needs that must be satisfied, as I have argued before, if humans are to be able to 
do anything at all. The natural - biological and environmental - realities affecting all of us will, indeed, ultimately shape whether or not the human race as a whole continues to reproduce itself.

Alison Assiter is Professor of Feminist Theory at the University of West England in Bristol. She has written a number of books and articles on feminist theory, political theory and more recently on Kant and Kierkegaard. Her most recent book is Kierkegaard, Eve and Metaphors of Birth (2015). She has also been politically active in areas relating to this journal.

\section{References}

AAPA Statement on Biological Aspects of Race. (1996) American Journal of Physical Anthropology 101 (4), pp. 569-570.

doi: 10.1002/ajpa.1331010408

Arendt, H. (1958) The Human Condition. Chicago: The University of Chicago Press.

Assiter, A. (1999) Enlightened Women. London: Routledge.

Assiter, A. (2003) Revisiting Universalism. Houndmills, Basingstoke, Hampshire: Palgrave Macmillan.

Assiter, A. (2015) Kierkegaard, Eve and Metaphors of Birth. London: Rowman and Littlefield.

Bernstein, R. (1985) Habermas and Modernity. Cambridge, Mass.: MIT Press.

Bhatt, C. (2006) The Fetish of the Margin: Religious Absolutism, AntiRacism and Postcolonial Silence. New Formations, Special Issue Postcolonial Studies After Iraq, 59, pp. 98-115.

Bordo, S. (1990) Feminism, Postmodernism and Gender Scepticism. In: L. Nicholson (ed.). Feminism/Postmodernism. London and New York: Routledge, pp.133-56.

Butler, J. (1990) Gender Trouble: Feminism and the Subversion of Identity. New York and London: Routledge. 
Calder, G. (2006) Soft Universalisms: Beyond Young and Rorty on Difference. Critical Review of International Social and Political Philosophy. 9 (1), pp. 3-21.

Crenshaw, K. (1991) Mapping the Margins: Intersectionality, Identity Politics and Violence against Women of Color. Stanford Law Review. 43 (6), pp. 1241-1299. Available from: http://www.jstor.org/stable/1229039

Dhaliwal, S. \& Yuval-Davis, N. (ed.) (2014) Women Against Fundamentalism, Stories of Dissent and Solidarity. London: Lawrence \& Wishart.

Fanon, F. (1967) Black Skin, White Masks. London: Pluto Press.

Fraser, N. \& Nicholson, L. (1990) Social Criticism without Philosophy. In: L. Nicholson (ed.). Feminism/Postmodernism. London and New York: Routledge, pp. 19-38.

Gilroy, P. (1993) The Black Atlantic: Modernity and Double Consciousness. London: Verso.

Grosz, E. (2011) Becoming Undone: Darwinian Reflections on Life, Politics and Art. Durham and London: Duke University Press.

Gunarsson, L. (2014) The Contradictions of Love, Towards a Feminist Realist Account of Socio-Sexuality. London: Routledge.

Hausmann, R., Tyson, L., Bekhouche, Y. \& Zahidi, S. (2014) The Global Gender Gap Index 2014. Geneva: World Economic Forum. Available from: http://www3.weforum.org/docs/GGGR14/GGGR_CompleteReport_2014. pdf [Accessed 26 November 2014].

Held, D. (1980) Introduction to Critical Theory: Horkheimer to Habermas. Berkeley: University of California Press.

Horkheimer, M. \& Adorno, T. (2002) Dialectic of Enlightenment. Translated by Edmund Jephcott. Stanford: Stanford University Press.

Lazarus, N. (1995) Is a Counterculture of Modernity a Theory of Modernity?. Diaspora: A Journal of Transnational Studies. 4 (3), pp. 323339.

Lazarus, N and Varma, R. "Marxism and Postcolonial Studies". Critical Companion to Contemporary Marxism, eds. Jacques Bidet and Stathis 
Kouvelakis (Historical Materialism Series: Brill Academic Publishers, 2008); pp. 309-331.

Lionnet, F. (1991) Dissymmetry Embodied: Feminism, Universalism and the Practice of Excision. Available from:

http://hdl.handle.net/2027/spo.4761530.0001.003 [Accessed 29 June 2016].

Lipsitz, G. (2006) Investment in Whiteness, How White People Profit from Identity Politics. Philadephia: Temple University Press.

Lyotard, J.F. (1979) The Postmodern Condition. Manchester: Manchester University Press.

Mahmood, S. (2011) The Politics of Piety: the Islamic Revival and the Feminist Subject. Princeton: Princeton University Press.

Modood, T. (2007) Multiculturalism. Cambridge: Polity Press.

Motahhari, M. (1990) Women's Rights in Islam, quoted in Misogyny in Power: Iranian Women Challenge Two Decades of Gender Apartheid. Auvers-sur-Oise, France: National Council of Resistance of Iran, Committee on Women.

Nussbaum, M. (1999) Sex \& Social Justice. New York: Oxford University Press.

Patel, P. (2013) Available from:

http://freethoughtblogs.com/godlessness/2013/10/06/pragna-patel-theright-to-blaspheme-is-a-matter-of-life-and-death/

Pateman, C. (1989) The Disorder of Women: Democracy, Feminism and Political Theory. Cambridge: Polity Press.

Poya, M. (2000) Double Exile, Iranian Women and Fundamentalism. In: N. Yuval-Davis \& G. Sahgal (ed.). Refusing Holy Orders, Women and Fundamentalism in Britain. London: Virago.

Rawls, J. (1971) A Theory of Justice. Cambridge: Harvard University Press.

Rorty, R. (1989) Contingency, Irony, and Solidarity. Cambridge: Cambridge University Press.

Ruthven, M. (1997) Islam: A Very Short Introduction. Oxford: Oxford University Press. 
Sa'dāwī, N. (2009) A Daughter of Isis. London: Zed Books.

Sahgal, G. (2014) Knowing my Place: The Secular Tradition and Universal Values. In: S. Dhaliwal \& N. Yuval-Davis (ed.). Women Against Fundamentalism, Stories of Dissent and Solidarity. London: Lawrence \& Wishart, pp. 67-83.

Slater, J. (2015) Richest 1\% will own more than all the rest by 2016 Oxfam / Blogs / Oxfam GB. Available from:

http://www.oxfam.org.uk/blogs/2015/01/richest-1-per-cent-will-ownmore-than-all-the-rest-by-2016 [Accessed 26 October 2015].

Spivak, G. (1997) Public Hearing on Crimes Against Women. WAF Journal. 7, pp. 3-5.

Taylor, C. (1992) Multi-Culturalism and the Politics of Recognition. Princeton: Princeton University Press.

Thompson, S. (2006) Political theory of recognition: A critical introduction. Cambridge: Polity Press.

Waltzer, M. (1983) Spheres of Justice. Oxford: Blackwell.

Werbner, P. \& Yuval-Davis, N. (1999) Women, Citizenship and Difference. London: Zed Books.

Whitford, M. (1991) Luce Irigaray: Philosophy in the Feminine. London: Routledge.

Wilkinson, R. (1996) Unhealthy Societies: The Afflictions of Inequality. London, New York: Routledge.

Wright, R., Kinnamon, K. \& Fabre, M. (1993) Conversations with Richard Wright. Jackson: University Press of Mississippi.

Young, I. (1989) Polity and Group Difference: A Critique of the Ideal of Universal Citizenship. Ethics. 99 (2), pp. 250-274.

Young, I. (1990) Justice and the Politics of Difference. Princeton: Princeton University Press.

\section{Notes}


${ }^{1}$ In various works of mine including my recent book Kierkegaard, Eve and Metaphors of Birth (2015).

2 It should be noted that Gilroy himself did not opt for the 'postmodern' alternative to the Enlightenment ideal. His concept of the 'black Atlantic' was deliberately intended to cross cultures and nations and suggested a common 'diasporic' identity. Neil Lazarus (1995, 323-339), however, has challenged the extent to which Gilroy's 'universalising' imperative about the diasporic identity is actually universalizing.

${ }^{3}$ See also David Held's, Introduction to Critical Theory (1980), Part Three, for a summary of critiques of these theories.

${ }^{4}$ These kinds of points have been made by Fanon in his major monograph, Black Skin, White Masks (1967).

${ }^{5}$ Mahmood, in her turn, argues that the language of rights, freedom and equality has contributed to undermining religious and cultural traditions that themselves enable certain groups of people to flourish.

${ }^{6}$ One famous example is the French Revolution which proclaimed to support the rights of 'man' but which explicitly excluded women from the scope of the public sphere (see Pateman 1989 and Werbner and Yuval-Davis 1999).

${ }^{7}$ A further common criticism of the human rights version of universalism is that it cannot decide between, for example, the competing rights of those who were and continue to be 'pro' choice versus those who campaigned against abortion. It has been argued that some in the 'global south' were being forced into reproduction controls. This was pointed out, for example, by Gayatri Spivak (1995, 3-5).

${ }^{8}$ In his magnum opus A Theory of Justice (1971), John Rawls hypothesized that principles of justice should be developed by people behind a 'veil of ignorance' about any of the qualities that differentiate them from others.

${ }^{9}$ A significant voice in the contemporary UK context is that of Tariq Modood, who offers a variant on some of the other theoretical perspectives, in his work Multiculturalism (2007).

${ }^{10}$ See Calder, op. cit, for an argument of this form. It ought to be pointed out that, although I am using the words 'universalist' and 'particularist', both words signify an idealised and general description of groups of people. Both are normative to the extent that they are attempting to specify significant commonalities between groups of people.

${ }^{11}$ See, for one example, the extensive work of Gill Hague and others, partly through The Centre for Gender and Violence Research at Bristol University.

${ }^{12}$ See also the work of Simon Thompson, 2006.

${ }^{13}$ Susan Bordo, quoting 'a historian' (1990, 133-56)

${ }^{14}$ It is also important to recognise the ground-breaking work of Judith Butler, who suggests that gender is a performative construction (Butler 1990).

${ }^{15}$ For some examples of this kind of argument, see Assiter (1999) and Gunarsson (2014).

${ }^{16}$ It doesn't follow that this distinction is not also social and psychological.

${ }^{17}$ If it is biological, then, a third category should be added - that of 'trans' people.

${ }^{18}$ Richard Wright, in conversation with a journalist in 1946, in Wright, Kinnamon

\& Fabre $(1993,99)$.

${ }^{19}$ This claim was made at a conference in London, October 2014, organized by Maryam Namazie and others, on Secularism and Anti-Fundamentalism. 
${ }^{20}$ The American Association of Physical Anthropologists make the following claim about this issue: 'Biological differences between human beings reflect both hereditary factors and the influence of natural and social environments. In most cases, these differences are due to the interaction of both. The degree to which environment or heredity affects any particular trait varies greatly.' (1996. 101, 569-570)

To cite this article:

Assiter, A. (2016). Why Universalism? Feminist Dissent, (1), 35-63. Retrieved from:

http://journals.warwick.ac.uk/index.php/feministdissent/article/view/7 